\title{
The Developments of the Competition Law in Macedonia (2014 Until Today)
}

\author{
Adnan Jashari* and Albana Metaj-Stojanova
}

Faculty of Law, South East European University, Rr. e Ilindenit, p.n., 1200, Tetovë-Tetova-Tetovo, Macedonia (The Former Yugoslav Republic)

\begin{abstract}
This article discusses the developments in the competition law of Republic of Macedonia with regard to the developments in the area of antitrust, abuse of dominant positions, concentrations, and state aid. The discussion is primarily focused in the legislative framework of the developments as well as in the relevant case law during the time period 2011-2015. In this article, an effort will be made to provide a general overview of some of the most important cases. In addition, this article will also to a certain extent discuss the progress made in the area of State aid. Last but not least, having in mind that competition law is also relevant area of reform required for the EU accession of R.M., the annual "progress reports" issued by the EU Commission regarding R.M. dealing with competition will be also addressed in this article.
\end{abstract}

Keywords: Community; Conservation; Conservation and development; Settlement

\section{The Law of Competition in Macedonia}

The new Law on protection of Competition ${ }^{1}$ [1] was adopted in 2010 and is fully in compliance with European provisions for Protection of Competition and in particular articles 101, 102, 106 and 107 of the TFEU. The Law entered into force in 2011 with amendments ${ }^{2}$ [2] performing and editing provision for the establishment of a procedure for giving effect to the principle that 'silence is consent ${ }^{3}$ [3]. These changes will contribute for faster and more efficient fulfillment of the rights both of citizens (consumers) and business.

All by-laws on the basis of LPC were adopted in 2005. Their application is still in force and after the adoption of the new Law in 2010, and the adoption of new regulations set by the new Law No. $145 / 10$. We have to note the adopted by-laws from 2005 in order to link them with the current regulations of 2011 year. They include the following: Regulation on block exemption granted to vertical agreements on exclusive right of distribution, selective right of distribution, exclusive right of purchase and franchise; Regulation on block exemption granted to horizontal research and development agreements; Regulation on block exemption granted to horizontal specialization agreements; Regulation on block exemption granted to technology transfer agreements, license or know-how; Regulation on block exemption granted to agreements on distribution and servicing of motor vehicles; Regulation on block exemption granted to agreements in the Insurance sector; Regulation on agreements of minor importance; Regulation on the form and the content of the notification and criteria on concentrations' evaluation ${ }^{4}$ [4].

In 2011 the Commission prepared nine draft regulations arising from LPC which had to be adopted by the government of Republic of Macedonia. Broad consultation process was conducted with all stakeholders, such as Ministries, the Institute of Industrial Property, the

'Law on protection of Competition, Official Gazette of RM, No.04/05 of RM, 70/60 and 22/07 was in force until 13/01/2010.

¿Law on protection of Competition. Official Gazette of RM, No. 136/11 which further harmonized the Law on protection of Competition. Official Gazette of RM, No.145/10 with Law on General Administrative Procedure. Official Gazette of RM 38/05, 110/08 and 51/1.

${ }^{3}$ Commission for Protection of Competition, Republic of Macedonia, The yearly report from the work of the Commission for protection on competition during 2014, March 2015.

${ }^{4}$ All these Regulations are published by the Official Gazette of R.M. no. 91/05.
National Bureau of Insurance Supervision, and the Union of Chambers of Commerce of Macedonia. The aim of these Regulations was perceived to be the achievement of a higher degree of harmonization of national legislation with the EU acquit. They include: Regulation for close terms on block exemption granted to technology transfer agreements, license or know-how transposing the EU Regulation 32004R0772.

Regulation for close terms on block exemption granted to research and development agreements transposing the EU regulation 32010R1217; Regulation for close terms on block exemption granted to horizontal specialization agreements transposing the EU regulation 32010R1218; Regulation on block exemption granted to Insurance agreements transposing the EU Regulation 32010r0267; Regulation on block exemption granted to agreements on distribution and servicing of motor vehicles transposing the EU Regulation 32010R0461; Regulation on block exemption granted to vertical agreements transposing the EU Regulation 32010R0330; Regulation on the form and the content of the notification and the necessary documents and criteria on concentrations' evaluation transposing the EU Regulation 32004r0820; Regulation for close terms on agreements of minor importance transposing the EU measure 52001XC1222(03); Regulation for close terms and procedure under which the Commission on misdemeanor decides to release or reduce the fine, transposing the EU measure 52006XC1208(04).

In 2011, the Commission carried out a broad consultation process with relevant stakeholders that resulted with the creation and adoption of three Guidelines regarding the application of the Law on protection of Competition. They are in particular important with regard to the harmonization process with EU competition rules. The Guidelines adopted are: 1. Guidelines on the manner of preparation of untrusted version of the decisions of the Commission (solutions

*Corresponding author: Jashari A, Faculty of Law, South East European University, Rr. e Ilindenit, p.n., 1200, Tetovë-Tetova-Tetovo, Macedonia (The Former Yugoslav Republic), Tel: 0038944356 149; E-mail: a.jashari@seeu.edu.mk

Received October 01, 2016; Accepted October 25, 2016; Published November 03, 2016

Citation: Jashari A, Metaj-Stojanova A (2016) The Developments of the Competition Law in Macedonia (2014 Until Today). Intel Prop Rights. 4: 168. doi: 10.4172/2375-4516.1000168

Copyright: @ 2016 Jashari A, et al. This is an open-access article distributed under the terms of the Creative Commons Attribution License, which permits unrestricted use, distribution, and reproduction in any medium, provided the original author and source are credited. 
that contain no data are confidential) (February 2011), consistent with the guidelines of DG Competition for market share-confidential version of the solution concentration; 2. Guidelines on defining the relevant market for the purposes of the Law on Protection of Competition $^{5}$ [5] harmonized with the EU measure 31997Y1209(01); Guidelines on restrictions, related directly and seen as necessary to the implementation of the concentration ${ }^{6}$ [6] harmonized with the EU measure 52005XC0305(02). It's also worth mentioning that before 2011 a number of Guidelines were transposed into our national legal system, including among others the: Guidelines on remedies acceptable to the Commission for Protection of Competition under Chapter III - Control of concentration - of the Law on Protection of Competition (2010); Guidelines on the assessment of vertical and conglomerate concentrations for the purposes of the LPC (November 2008); Leaflet on the Regulation on block exemptions granted to vertical agreements on exclusive right of distribution, selective right of distribution, exclusive right of purchase and franchise (October 2007); Guidelines on defining relevant market for the purposes of the Law on Protection of Competition (April 2007); Guidelines to the Law on Protection of Competition (April 2007); Guidelines on the assessment of horizontal concentrations for the purposes of the Law on Protection of Competition (April 2007); Information Leaflet on Concentration Control (April 2007).

Competition Law in RM prohibits anti-competitive agreements, cartels as well the abusive conduct by undertakings that have a dominant position on a market. What characterizes the area of competition law in RM in this period is the decisive role of the Commission for Protection of Competition. Three features of the Commission's work in $2015^{7}$ [7] are noted in this article:The conduct of administrative and misdemeanor procedures for determining the existence of offenses set out in the Law on protection of Competition; the analysis of the certain markets and the recommendations and opinions given.

As mentioned above, the Law on protection of Competition establishes three basic forms of action of undertakings that may prevent, restrict or distort competition in Macedonian market, such as prohibited agreements, abuse of dominant positions, and prohibited concentrations. Accordingly, the Commission for protection of competition covers the following areas: evaluation of agreements between undertakings; prevention and elimination of the abuse of dominant position, and control of concentrations.

In accordance with this Law, the procedures in these areas until November 2013 were conducted primarily as administrative proceedings before the Commission. If the Commission during the administrative proceedings had determined that there has been prohibited agreement or abuse of dominant position after the final completion of the administrative proceedings than would go through the misdemeanor proceedings for the same case. With the adoption of new law on protection of competition, 145/10 and 136/11 assessing the agreements between undertakings and also the prevention and

${ }^{5}$ Official Gazette of Republic of Macedonia no.145/10, the Guidelines on defining the relevant market are fully harmonized with Commission notice on the definition of the Relevant Market for the purposes of Community competition law, Official Journal C 372, 09.12.1997, p. 5.

${ }^{6}$ The Commission for Protection of Competition in accordance with article 28 Para. (3) Linked with article 25 from Law on protection of Competition 145/10 I 136/11 on the meeting held on Nov. 26. 2011 broad them in accordance with OJ C 56, 5.3.2005 pages 24-31, Celex 52005XC0305(02)

${ }^{7}$ Commission for Protection of Competition, Republic of Macedonia, The yearly report from the work of the Commission for protection on competition during 2014 adopted in March 2015. elimination of the abuse of dominant position are handled only as infringement procedures.

\section{Assessment of the Agreements Concluded Between Undertakings from 2014 until Today}

In accordance with the Law on protection of Competition all agreements concluded between subjects, decisions by the subjects and concerted practices which have as their object or effect the distortion of competition, are prohibited by law. Article 7 of the Law on Protection of Competition enumerates:

1. Directly or indirectly fix purchase or selling prices or any other trading conditions;

2. Limit or control production, markets, technical development or investments;

\section{Share markets or sources of supply;}

4. Apply dissimilar conditions to equivalent or similar transactions with other trading parties, thereby placing them at a competitive disadvantage;

5. Make the procedural order of agreements subject to acceptance by the other parties of supplementary obligations, which, by their nature or according to commercial usage, have no connection with the subject of such agreements.

On the other side, these provisions shall not apply to agreements, decisions of associations of undertakings and concerted practices that contribute to promoting the production or distribution of goods and services or to promoting technical or economic development, provided that the consumers have a proportionate share of the resulting benefit, and which: do not impose on the undertakings concerned restrictions which are not indispensable to the attainment of these objectives, and do not afford such undertakings the possibility of eliminating competition in respect of a substantial part of the products or services in question.

As an exception and when necessary for protecting the public interest related to the application of Article 7 of the LPC may, acting on its own initiative, established by means of a decision that this article is not applicable to an agreement, a decision of an association of undertakings or a concerted practice because the conditions of Article 7 paragraph (1) of this Law are not fulfilled or because the conditions of Article 7 paragraph (3) of this Law are satisfied.

\section{Case Law Concerning the Prohibited Agreements form 2014 Until Today}

In 2014 the Commission for Protection of Competition (CPC) initiated an ex officio procedure and conducted just one misdemeanor proceeding for the existence of prohibited agreement. In the meantime, the Commission conducted again another ex officio procedure, adopted for decisions finding prohibited agreements, as follows:

1. Decision of the CPC no. 09-2/14 date 31.03.2014 according to which, in a procedure established by virtue of office (ex officio) against Alkaloid Kons, export-import Single-member LLC, Skopje and "D-KVK", pharmaceutical and medical equipment trading and services Joint-stock company, Skopje, the Commission concluded that these two companies had acted in a harmonized way and in agreement during the submission of their offerings to supply a drug with generic name Docetaxel injections/vial 20, therefore a fine was imposed. 
2. Decision of the CPC no. 09-17/77 date 21.10.2014, according to which in a procedure established by virtue of office against EFT Makedonija, Single-member LLC for production, trade and services, Skopje, EZPADA electrical trading Single-member LLC, Skopje, RUDNAP electrical trading Single-member LLC, Skopje, GEN-I electrical trading and selling Single-member LLC, Skopje and GEN-I electrical trading and selling LLC, Krsko, Slovenia, the CPC found that the aforementioned undertakings had participated in a prohibited agreement - cartel in public procurement. Exactly the same undertakings submitted bids for the sale of electricity at previously defined prices and amounts in a way that allowed them to share the quantities of electricity that would be ordered by ELEM JSC (ELEM JSC deals with supplying electricity to consumers - households and undertakings that are connected to the electricity distribution system). In relation to these offences the Commission imposed a fine on the abovementioned companies.

3. Decision of the CPC no. 09-2/23 date 06.11.2014, according to which in a procedure established ex officio against Alkaloid Kons, export-import Single-member LLC, Skopje, and "D-KVK", pharmaceutical and medical equipment trading and services Jointstock company, Skopje, the Commission found that the aforesaid wholesalers have acted in a harmonized way in submitting bids for the supply of the drug Docatexel for two clinics in Macedonia during a period of time from 18.02.2008 until 20.07.2009. Hence, the Commission imposed fines.

\section{Abuse of the Dominant Position from 2014 until Today $[8]^{8}$}

Like EC competition law, Macedonian competition law prohibits the abuse of a dominant position of a certain undertaking. Law on protection of Competition prohibits any abuse of dominant position by one or more undertakings on the relevant market or its essential part [9]. ${ }^{9}$ Chapter Two of this Law provides the provisions about the dominant market position and distortion of competition, in particular Article 10 and Article 11 of the same Law deal with the abuse of dominant position. The relevant geographical market is Macedonia or its substantial part, thereof depending on the nature of the product involved. It should be noted that the dominant position is not prohibited per se, just in cases were the abuse is evidenced in accordance with the prescribed law.

\section{By Laws of Abuse of Dominant Position}

This Law envisages six situations containing the abuse of the dominant position ${ }^{10}[10]$, those are, when two or more undertakings: directly or indirectly imposing unfair purchase or selling prices or other unfair trading conditions; limiting production, markets or technical development to the prejudice of consumers; applying different conditions to equivalent (or similar) legal transactions with other trading partners, thereby placing them in a position of competitive disadvantage; making the procedural order of agreements subject to acceptance by the other parties of supplementary obligations, which, by their nature or according to commercial usage, have no connection with the subject of such agreements; unjustified refusal to deal or encouraging and requesting from other undertakings or association

${ }^{8}$ For definition of dominat position see: B.Van, Competition law of European Community,Kluwer Law International, 2005,p. 117

'Law on protection of Competition, Official Gazette of RM, No.145/10.

${ }^{10}$ See more for abuse of dominant position; R. Whish, D. Bailey, Competition Law Seventh edition, Oxford University Press, 2012, p.681. of undertakings not to purchase or sell goods and/or services to a certain undertaking, with an intention to harm that undertaking in a dishonest manner; Unjustified refusal to allow another undertaking access to its own network or other infrastructure facilities for adequate remuneration, if without such access, as a result of legal or factual reasons, the other undertaking becomes unable to operate as a competitor on the relevant market [11]. ${ }^{11}$

\section{Case Law Regarding the Abuse of Dominant Position from 2014 Until Today}

In 2014, the Commission issued 4 decisions in misdemeanor procedure in which was found existence of abuse of a dominant position, including:

1. Decision of the CPC no. 09-3/8 date 31.03.2014, according to which in a procedure established ex officio against PE Komunalna Higiena - Skopje, the CPC found that PE Komunalna Higiena Skopje, abused its dominant position on the market for municipal waste from the City of Skopje, resulting in denial of market acces for another enterprise (EKO KLUB Single-member LLC) and by that the enterprise was prevented from acting as a competitor in the relevant market in a period of time from 31.12.2006 until 15.01.2007. Therefore the Commission imposed a fine.

2. Decision of the CPC no. 09-4/9 date 04.04.2014, according to which in a procedure initiated upon the request of a natural person (P.D.) against PECA (Public Enterprise for Communal Activities) Komunalec Gevgelija, the Commission found that PECA Komunalec Gevgelija has abused its dominant position on the market of construction, reconstruction, administration and maintenance of cemeteries in the territory of Gevgelija in a period of time from 22.01.2009 until the date of approval of this decision. When conducting solidar burial services, the enterprise did not foresee the possibility of reimbursement of means for the solidar users of funeral services in case of use of funeral and burial services from other companies that offer these services and for this offence the Commission imposed a fine.

3. Decision of the CPC no. $09-28 / 2$ date 15.09 .2014 , made in a procedure initiated upon the request of a company for production, trade and services against PE Ohridski Komunalec, Ohrid, accrding to which the Commission found that PE Ohridski Komunalec has abused its dominant position on the market of construction, reconstruction, administration and maintenance of cemeteries in the territory of the Municipality of Ohrid in a period of time from 25.05.2010 until 04.01.2011, by directly imposing unfair trading conditions in a way that upon signing of an agreement on access and use of the infrastructure of City of Ohrid cemetery, administered by PE Ohridski Komunalec, the enterprise unjustifiably imposed on funeral services operators payment of a fixed amount of 150 Euros per month in the name of maintaining public hygiene and cleaning of the entire infrastructure that a funeral services operator uses when conducting a funeral. Hence, the Commission imposed a fine.

4. Decision of the CPC 09-13/9 date 24.12.2014, according to which in a procedure initiated upon the request of a natural person (A.T.) against PE Komunalec Prilep, the Commission found that PE Komunalec Prilep has abused its dominant position on the market of construction, reconstruction, administration and maintenance of cemeteries in the territory of the Municipality of Prilep in a period of time from 13.11.2010 until the date of approval of this decision. When conducting solidar burial services the enterprise did not foresee

${ }^{11}$ Law on protection of Competition, Official Gazette of RM, No.145/10, Article 11. 
the possibility of reimbursement of means for the solidar users of funeral services in case of use of funeral and burial services from other companies that offer these services, therefore the Commission imposed a fine on PE Komunalec Prilep [12].

\section{Concentrations ${ }^{12}$}

The third chapter of the Law on protection of Competition is dedicated to the concentrations [13]..$^{13}$ Under article 12 of the abovementioned law a concentration shall be de deemed to arise where a change of control on a lasting basis results from: - the merger of two or more previously independent undertakings or parts of undertakings, or - the acquisition of direct or indirect control of the whole or parts of one or more other undertakings by one or more persons already controlling at least one undertaking, or one or more undertakings, whether by purchase of securities or assets, by means of an agreement or in other manner stipulated by law.

Concentrations are considered as merger or acquisition of certain subjects in order to make their business more efficient. By joining, the undertakings establish a dominant position in a particular market or market share, which by abusing the market, may violate the fair competition. Legally, during the merger or acquisition of undertakings the subjects of law may or may not lose their legal independence. In these circumstances, the loss of the legal independence is not as important as the fact whether changes or not the economic power of the subjects they create with the concentration. Therefore, the entities that create the concentration are obliged to inform the competent body for protection of competition, in order to verify that the concentration for which information is delivered can cause restriction or elimination of competition in the market or is within the permitted framework.

\section{By Laws of Concentrations}

In accordance with LPC the participants in a certain concentrations are obliged to send a notification to the Commission if a change regarding the control occurs. The concentration shall notify the Commission for Protection of Competition if the following conditions are met:

1. The aggregate turnover of all undertakings participants, generated by sale of goods and/or services in the world market, amounts to at least 10 million euro in MKD equivalence according to the exchange rate valid on the day of compiling the annual account, realized in the business year preceding the concentration and provided that at least one participant must be registered in the Republic of Macedonia, and/or

2. The aggregate turnover of all undertakings participants, generated by sale of goods and/or services in the Republic of Macedonia, amounts to at least 2.5 million euro in MKD equivalence according to the exchange rate valid on the day of compiling the annual account, realized in the business year preceding the concentration, and/or

3. The market share of one of the participants amounts to more than $40 \%$ or the total market share of the participants in the concentration amounts to more than $60 \%$ in the year preceding the concentration.

During 2014, the Commission in administrative procedure has approved 30 decisions related to the control of concentracions. From a total of 30 decisions related to concentractions, on 29 decisions it is

${ }^{12}$ For concentrations see more: A. jashari, N. Ziba, Important aspects of concentrations in Republic of Macedonia, International journal of Business Socia research, vol. 2 no.2, 2012

${ }^{13}$ Law on protection of Competition, Official Gazette of RM, No.145/10, Articles 12-25. found that concentrations are in accordance with the provisions of the Law on Protection of Competition, and in one decision the Commission finds that the concentration does not fall under the provisions of the Law on Protection of Competition [14]. ${ }^{14}$

\section{Case Law Regarding Concentrations form 2014 until Today}

In 2014, 29 notifications of concentrations were submitted to the Commission. In 2014, the Commission approved 30 decisions.

In 29 decisions it was found that the concentration, although falling under the provisions of the Law on Protection of Competition, it will not have the effect of significantly preventing, restricting or undermining effective competition on the market, or an essential part of it, especially as a result of creation or strengthening of a dominant position and is in accordance with the provisions of LPC, as follows:

1. Decision no. 08-144 date 09.01.2014 on concetration between Adria Media Limited, Cyprus and IKO Balkan S.R.L., Bucharest, Romania, based on the sale and purchase of shares. The participants in concentration are active on the market of production and distribution of TV channels.

2. Decision no. 08-145 date 09.01.2014 on concentration between Slovenia Broadband S.a.r.l., Luxembourg and Solford Trading Limited, Cyprus, based on the sale and purchase of shares. The participants in concentration are active on the market of Net TV Plus program platform and IP Television.

3. Decision no. 08-148 date 09.01.2014 on concentration between Remho Beteiligungs GmbH, Vienna, Austria (AlserbachstraBe 14-16 Palais Liechtenstein, 1090 Wien, Austria) and HELIOS sestavljeno podjetje za kapitalske nalozbe in razvoj, d.d., Republic of Slovenia (Kolicevo 2, 1230 Domzale, Slovenija), based on the sale and purchase of shares. The participants in concentration are active on the production and sales of colours market.

4. Decision no. 08-149 date 09.01.2014 on concentration between natural person K.G., citizen of the Republic of Bulgaria and Direct Media LLC, Belgrade, Serbia. The participants in concentration are active on the marketing services market.

5. Decision no. 08-150 date 31.01.2014 on concentration between SAGA LLC Belgrade, Novi Sad, Serbia, based on the sale and purchase of sales. The participants in concentration are active on the IT solutions and IT services market.

6. Decision no. 08-152 date 06.03.2014 on concentration between the trading company Adris grupa d.d., Rovinj, Republic of Croatia and Kroacija Osiguruvanje d.d., Zagreb, Republic of Croatia, based on the sale and purchase of shares. The participants in concentration are active on the insurance services market.

7. Decision no. 08-153 date 06.03.2014 on concentration between Deutsche Telekom AG, Bon, Federal Republic of Germany and Consortium 1 S.a.r.l, Luxembourg, based on the sale and purchase of shares. The participants in concentration are active on the telecommunications services market.

8. Decision no. 08 -154 date 06.03 .2014 on concentration between Overseas Transport Holding Gmbh, Lauterach, Austria and WeissRohlig China Ltd, Hong Kong, Kowloon, China, Weiss-Rohlig Taiwan Ltd, Taipei, Taiwan, Weiss-Rohlig Middle East Ltd, Dubai, Weiss-

${ }^{14} \mathrm{Annual}$ report of the Commission for protection of competition for 2015. 
Rohlig Holding GmbH, Lauterach, Austria, Weiss- Rohlig Canada Inc., Toronto, Canada, based on the sale and purchase of shares. The participants in concentration are active on the carriage services market in the field of international aviation and maritime transport.

9. Decision no. 08-156 date 24.03.2014 on concentration between Kuhenberger Eastern Europe GmbH, Austria and Logwin Solutions, Single-member LLC, Stip, Macedonia, specialized in international transportation of goods, based on the sale and purchase of shares. The participants in concentration are active on freight transport market.

10. Decision no. $08-158$ date 24.03 .2014 on concentration, according to which Fater S.p.A, Italy acquires means for production, packaging, distribution, marketing, sales and control of Procter \& Gamble group, headed by Procter \& Gamble Company, headquarted in 1 Procter \& Gamble Plaza, Cincinnati, Ohio, USA. The participants in concentration are active on the laundry additives market.

11. Decision no. 08-160 date 24.03.2014 on concentration, according to which Pamplona Capital Partners III, L.P., Cayman Islands, through its associate company, PHM Topco 21 S.a.r.l., Luxembourg will gain control over Alvogen Lux Holdings S.a.r.l., Luxembourg, based on the sale and purchase of shares. The participants in concentration are active on the market for production and sales of pharmaceutical products.

12. Decision no. 08-161 date 10.04.2014 on concentration between Visteon Corporation, Wilmington, New Castle County, Delaware, USA and Johnson Controls Macedonia, Single-member LLC, Skopje, Ilinden, Skopje, Macedonia, based on gain of control. The participants in concentration are active on the market for manufacture and supply of vehicle parts in the automotive industry.

13. Decision no. 08-162 date 10.04.2014 on concentration between Nova Ljubljanska Banka d.d., Ljubljana, Slovenia, SID Slovenska izvozna in razvojna banka d.d. Ljubljana, Ljubljana, Slovenia and FIM Bank p.l.c., Malta on one side and Prvi Faktor LLC., Ljubljana, Slovenia on the other, based on gain of control. The participants in concentration are active on the banking services market.

14. Decision no. 08-165 date 14.05.2014 on concentration between Eurostandart Banka JSC Skopje, Skopje, Macedonia and Poshtenska Banka JSC Skopje, Skopje, Macedonia, based on gain of control. The participants in concentration are active on the banking services market.

15. Decision no. 08-167 date 15.05.2104 on concentration between Carso Telekom B.V., Amsterdam, Netherlands (Prins Bernhardplein 200, 1097 JB Amsterdam, the Netherlands) and Telekom Austria Aktiengesellschaft, Vienna, Austria (Lassallestrasse 9, 1020 Vienna, Austria), based on the sale and purchase of shares. The participants in concentration are active on the telecommunications market.

16. Decision no. 08-166 date 22.05.2014 on concentration between natural person F.S. Skopje, Macedonia and Trading company for representation, services and wholesale and retail trade AKCENT MEDIA National Advertising Agency export-import, Single-member LLC Skopje, Skopje, Macedonia. The participants in concentration are active on the media advertising market.

17. Decision no. 08-170 date 30.05.2014 on concentration between United Media S.a.r.l., Great Principality of Luxembourg, Grand Slam Group LLC, Belgrade, Serbia and natural person A.P. from Serbia on one side and Grand Production LLC, Belgrade, Serbia on the other, based on the sale and purchase of shares. The participants in concentration are active on the sound recording and musical house market.
18. Decision no. 08-171 date 30.05.2014 on concentration between Philip Morris International Management SA, Lausanne, Switzerland and Tutunski kombinat JSC, Prilep, Macedonia, based on joint investment. The participants in concentration are active on the market for the manufacture and supply of tobacco products/cigarettes.

19. Decision no. 08-172 date 03.07.2014 on concentration between CAS-One Holdinggesellschaft mbH, Hanover and Emitec Gesellschaft für Emissionstechnologie $\mathrm{mbH}$, Lohmar, Germany, based on gain of shares. The participants in concentration are active on the market for production of products for treatment of gases used for various purposes, including vehicles, stationary and mobile machinery, power plants, locomotives and ships.

20. Decision no. 08-173 date 03.07.2014 on concentration between Slovenia Broadband S.a.r.l. Luxembourg, Great Principality of Luxembourg and AD Broadband Montenegro, Podgorica, Montenegro, based on the sale and purchase of shares. The participants in concentration are active on the telecommunications market.

21. Decision no. 08-174 date 24.07.2014 on concentration between Mobilkom Mazedonien Beteiligungsverwaltung GmbH Vienna, Austria and Blizoo media and broadband Single-member LLC Skopje, Skopje, Macedonia, based on the sale and purchase of shares. The participants in concentration are active on the telecommunications market.

22. Decision no. $08-175$ date 08.08 .2014 on concentration between Principality of Liechtenstein and Mobilkom Beteiligungsgesellschaft $\mathrm{mbH}$, Vienna, Austria on one side and Telecom Liechtenstein AG, Liechtenstein on the other, based on the acquisition of joint control. The participants in concentration are active on the telecommunications market.

23. Decision no. 08-177 date 08.08 .2014 on concentration between Hemofarm JSC Vrsac, Republic of Serbia and Pharmanova LLC Obrenovac, Belgrade, Serbia based on gaining control through purchase of assets. Hemofarm JSC Vrsac acquired means for production and sale of certain pharmaceuticals products owned by Pharmanova LLC Obrenovac. The participants in concentration are active on the manufacturing and sale of pharmaceutical products market.

24. Decision no. 08-178 date 08.08.2014 on concentration between Alpha Bank A.E. Athens, Republic of Greece on one side and CitiBank International PLC, London, United Kingdom and Diners Club of Greece Finance Company S.A. Athens, Republic of Greece on the other, based on gain of control. The participants in concentration are active on the banking services market.

25. Decision no. 08-179 date 08.08.2014 on concentration between Archer Daniels Midland Europe B.V., Netherlands, Archer Daniels Midland Europoort B.V., Netherlands and ADM Germany GmbH Hamburg, Germany on one side and WILD Flavors GmbH, Switzerland and WILD Dairy Ingredients GmbH, Germany, based on gain of control. The participants in concentration are active on the taste systems market.

26. Decision no. 08-180 date 05.09.2014 on concentration between United Media S.a.r.l., Luxembourg and Orlando Klinci d.o.o. Zagreb, Republic of Croatia, based on gain of control. The participants in concentration are active on the telecommunications market.

27. Decision no. 08-182 date 25.11.2014 on concentration between Telemax Company for service delivery in the field of telecommunications LLC, Sarajevo, Ilidza - Sarajevo, Bosna and 
Herzegovina and BHB KEJBL TV LLC Lukavac, Lukavac, Bosna and Herzegovina, based on the sale and purchase of shares. The participants in concentration are active on the telecommunications market.

28. Decision no. 08-183 date 25.11.2014 on concentration between Telemach for wide communication LLC, Ljubljana, Slovenia and Tusmobil LLC for mobile communications services, Ljubljana - Crnuce, Slovenia, based on the sale and purchase of shares. The participants in concentration are active on the telecommunications market.

29. Decision no. 08-185 date 24.12.2014 on concentration between Blizoo Media and Broadband Ltd Skopje, a company for telecommunication engineering, software, trade and services on one side and Trading company for broadcasting - cable network operator ASTRA PLUS LLC, Kocani, Trading company for hiring people with disabilities - protected company for broadcasting - cable network operator Filadelfija 2002 LLC, Kocani, Trading company for broadcasting - cable network operator KABEL RIZ LLC, Kocani, Company for production, trade and services SISTEM KABEL Singlemember LLC export - import, Miladinovci, Ilinden and Services and trade company SPEJS TEL NET Single-member LLC Kadino, Ilinden on the other, all Macedonian companies, based on gain of control. The participants in concentration are active on the market for provision of services for the transmission of audio-visual content to the end users and the market for the provision of services for fixed Internet access with larger volume.

According to the decision no. 08-176 date 05.09.2014, the Commission ascertained that the concentration between natural person A.B. from Skopje, Macedonia and MM Investment LLC Skopje, Macedonia, based on the sale and purchase of shares, does not fall under the provisions of the LPC.

\section{State Aid}

According to the Stabilization and Association Agreement (SAA) between Macedonia and the European Communities and their Member States the important legal provisions applying at EU level are transposed into our legislation. What is a State aid and when state aid can distort competition in one state being or willing to be a Member State?

\section{Legal Framework}

The law in force on state aid [15] ${ }^{15}$ is the Law on State Aid Control which entered into force in 2010 [16]. ${ }^{16}$ The Law regulates the forms of state aid, the general conditions and the rules for notifying state aid and the assessment and monitoring of the state aid. The objective is to establish rules for notification, approval, granting and monitoring of state aid with a view to implementing the principles of the market economy, providing free competition and fulfilling the obligations undertaken by the Republic of Macedonia through ratified international treaties containing provisions for state aid [17]. ${ }^{17}$ According to Article 2 of the Law on State Aid Control, the law is applicable to any form of state aid granted by state aid providers, irrelevant whether it is granted under an aid scheme or as an individual aid award, and which may affect the trade in the Republic of Macedonia, trade between the Republic of Macedonia and the European Union, as well as trade between the

${ }^{15}$ Law on State Aid, Official Gazette of RM, 24/03, 70/06 and 55/07 are no longer in force.

${ }^{16}$ Law on State aid control, Official Gazette of RM 145/10.

${ }^{17} \mathrm{lbid}$, Article 2
Republic of Macedonia and other countries which together with the Republic of Macedonia are parties to ratified international agreements containing state aid provisions [18]..$^{18}$ The same Article states that it will not be applicable to state aid granted in the sector of agriculture and fisheries [19]. ${ }^{19}$ The last paragraph of Article 2 it is also very important stating that during the assessment of the forms of state Aid that may affect the trading between the Republic of Macedonia and the European Communities, in accordance with Article 69 of the Stabilization and Association Agreement concluded between the Republic of Macedonia and the European Communities and their member-states, the criteria arising from the proper application of the rules regulating state aid in the European Union shall be accordingly applied. From the data of 2014 can be concluded that the participation of State aid in 2014 compared to GDP is $0.08 \%$. The total amount of state aid that was allocated that year was $448,277,000.00$ denars.

Pursuant to Article 5, paragraph 2 and in accordance with Article 5, paragraph 1 (b), of the Law on State Aid, ${ }^{20}$ the Government of the Republic of Macedonia, in its session held on $21^{\text {st }}$ December 2007, adopted: Regulation on establishing conditions and procedure for granting horizontal Aid. ${ }^{21}$ On the basis of article 6 paragraph (4) of the Law on State aid, ${ }^{22}$ the RM, on a session held on 15.12.2003 year, issued Regulation on establishing conditions and procedures for granting regional aid. ${ }^{23}$ On the basis of Article 11 paragraph (2) of the State Aid Law, ${ }^{24}$ the Government of the RM, on a session held on 15.12.2003 year, issued Regulation on the forms and procedure of notification to the state aid commission and for assessment of state aid. ${ }^{25} \mathrm{On}$ the basis of Article 8 of the State Aid Law ${ }^{26}$, the Government of the RM, on a session held on 15.12.2003 year, issued Regulation on establishing conditions and procedure for granting aid for rescue and restructuring of firms in difficulty. ${ }^{27} \mathrm{New}$ regulations were adopted also in 2008 and 2009, and finally based in these and others non mentioned juridical acts in 2010 the Parliament of R. M. adopted the new law in the area of state aid.

\section{Case law on the area of state aid form 2014 until today}

During 2014, the Commission issued 11 decisions dealing with state aid control. On 6 decisions the Commission ascertained that the measures contained in the notifications submitted to it by the state aid provider represent state aid under the Law on State aid control, while according to the other 5 decisions the Commission found that the measures contained in the notification represent aid of minor

\footnotetext{
${ }^{18} \mathrm{lbid}$, Article 3.
}

${ }^{19}$ Law on State Aid control, Official Gazette of RM, 145/10, Article 3, paragraph 2.

${ }^{20}$ Law on State aid, Official Gazette of RM, 24/03; 70/06; and 55/07.

${ }^{21}$ Regulation on establishing conditions and procedure for granting horizontal Aid Official Gazette of the Republic of Macedonia No. 157 (27th December 2007)-

${ }^{22}$ Law on State aid, Official Gazette of RM, 24/03.

${ }^{23}$ Regulation on establishing conditions and procedures for granting regional aid Official Gazette of the Republic of Macedonia No. 15.12.2003.

${ }^{24}$ Law on State aid, Official Gazette of RM, 24/03.

${ }^{25}$ Regulation on the forms and procedure of notification to the state aid commission and for assessment of state aid Official Gazette of the Republic of Macedonia No. 15.12.2003

${ }^{26}$ Law on State aid, Official Gazette of RM, 24/03.

${ }^{27}$ Regulation on establishing conditions and procedure for granting aid for rescue and restructuring of firms in difficulty Official Gazette of the Republic of Macedonia No. 15.12 .2003 
importance ${ }^{28}$, respectively aid allocated to a user which does not exceed 200,000 euros for a period of three years.

Categories for which state aid was allocated in 2014 are: support of small and medium enterprises; support and development of the cluster grouping; implementation of industrial policy; tourism (touristic events and forums); national restaurant-cafés; employment; financial support of legal entities; preparation for employment through training; tourism promotion and support for subsidizing organized foreign tourism and environmental protection.

In 2014 the Commission for Protection of Competition adopted decisions after the filing of the Notice for planned state aid for regional development by the state aid providers. Such decisions are adopted by the Commission for Protection of Competition for planned division of the regional state aid, which as such is consistent with the goals of regional policy of the Republic of Macedonia, supporting productive initial investments or the creation of new jobs associated with the investments. From what was said it can be concluded that in 2014 also, the investment of foreign investors in the Republic of Macedonia continues, especially in the technological industrial development zones, aimed to improve, grow and economically develop the country.

From the data of 2014 we can conclude that with the majority of state aid providers is established continuity in fulfilling the obligations deriving from the implementation of state aid legislation, and this enables uninterrupted evaluation, control and supervision of such state aid in those areas by the Commission.

State aid by instruments: In relation with the instruments by which state aid is allocated and for which notifications are submitted and for which a decision is adopted by the Commission during 2014, it can be concluded that the state aid allocated in 2014, is divided by group A instruments.

Commission opinions. In 2014, the number of opinions given by the Commission for Protection of Competition is 19. The large number of opinions that the Commission for Protection of Competition has adopted during 2014, is due to the need of state aid providers to get an opinion from the Commission starting from the phase of preparation of bylaws, which in itself may contain elements of state aid, as well as the need for evaluation of the proposed agreements for division of state regional aid for potential users.

Comments and conclusions. The trend of continuos demand of opinions and submitted notifications - notifications that come from Ministries is evident, and it is a result of the considerable increase of awareness for the importance that this area has, as an important part of the field of protection of competition and changes introduced in the legislation. In the same time, the Commission is in constant nonformal communication with all state aid providers in need of any information about the planned measures for allocating state aid from the grantor. Also, in regard of the Europian integration the correct implementation of the legislation on state aid, is not less important. The data on the divided state aid in the Republic of Macedonia, show that state aid is largely allocated to support projects that have a direct impact on the economy of the state, particularly through the implementation of projects that promote economic development of areas in Macedonia, where the standard of living is low or where the unemployment rate is high. Namely, it comes to state aid allocated to regional development which supports foreign investments in the country, through subsidizing companies which invest in Macedonia.

${ }^{28} \mathrm{Annual}$ report of the Commisssion for protection of competition for 2015 .
On the other hand, through development programs, the state has participated through the mechanism of state aid in the support and development of tourism where aid providers are the Ministry of Economy and the Agency for Promotion and Support of Tourism. Also, the Ministry of Economy through the Proposal Program for competitiveness, innovation and entrepreneurship in 2014 was presented as a provider of state aid for the support of small and medium enterprises, implementation of industrial policy, as well as support and development of cluster grouping. The state also through granting state aid helped in some parts of the measures of the Operating plan for active programs and measures for employment in 2014, where provider of state aid is the Ministry of Labour and Social Policy. In this context, the state, through granting state aid by the Ministry of Environment and Physical Planning, helped in protecting the environment through the implementation of concrete measures, which are part of the Programme for the Protection of the environment for 2015.

\section{EU Progress Report ${ }^{29}$}

In the area of competition policy good progress has been made. The legislation additionally is harmonized with the European legislation and the Criminal Code is harmonized with the Law on Competition Protection.

Inter-agency cooperation in the area of European integration. The Commission is bearer of the Working Group NPAA 3:08 (Competition policy) and is responsible for the implementation of necessary activities in legislative and institutional terms in order to fulfill the conditions for membership of Macedonia in EU. The Commission regularly has participated in the monthly meetings of the Working Committee for European Integration (WCEI) and the Sub-committee of WCEI in the Secretariat for European Affairs (SEA). At these meetings, the Commission regularly informed the heads of SEA about the achieved progress in terms of harmonization of national legislation with the EU acquis and strengthening of administrative capacities for the implementation of legislation, as well as for the degree of realization of the activities foreseen in chapter 08 of the National Programme for the Adoption of EU acquis for 2014-2016 (NPAA 2014- 2016).

Bilateral and multilateral cooperation. During 2014, the cooperation with the authorities responsible for implementing competition legislation in the countries of the region and member states of the EU, launched in previous years, continued and increased. New projects were also initiated in the framework of international organizations. In 2014, bilateral cooperation with the organs of competition protection of the region, was intensively conducted which further represents an important element of the international cooperation of the Commission, based on the exchange of various experiences on issues of accession of these countries in the European Union, but also in processes and adaptations of the market economy in a broader sense. In February 2005, the Organization for Economic Cooperation and Development (OECD) - Regional Competitiveness Center was formed in Budapest, Republic of Hungary, which organizes seminars and trainings for the employees of the competent competition authorities in countries of Eastern Europe. From 3 to 5 June 2014, a Seminar on cartels in supply, organized by OECD - Regional Competitiveness Center in collaboration with the Commission for Protection of Competition was held in Skopje. The seminar was attended by experts on the competition policy from the OECD, France, Romania, Finland, Hungary, representatives of bodies of competition from countries

${ }^{29}$ European Commission, Brussels, 15.9.2014 COM(2014) 575 final ,Report from the European Commission for the progress of RM in 2014 regarding the section 08 of the Competition Policy. 
Citation: Jashari A, Metaj-Stojanova A (2016) The Developments of the Competition Law in Macedonia (2014 Until Today). Intel Prop Rights. 4: 168. doi: $10.4172 / 2375-4516.1000168$

Page 8 of 8

such as: Albania, Azerbaijan, Bosnia Herzegovina, Bulgaria, Belarus, Kyrgyzstan, Kazakhstan, Kosovo, Moldova, Armenia, Serbia, Ukraine, Croatia, Russia and Romania. Republic of Macedonia is a member of the International Competition Network (ICN).

\section{Conclusion}

Protection of Competition is a legal issue that has been continuously amended at the EU level, hence monitoring and adjusting the national legislation as a continuous process with the main task of the Commission for Protection of Competition as precondition for membership. Today, the responsibility for the effective implementation of the century harmonized legislation in the field of competition is shared between the CPC and the Administrative court. The Commission continues to carry out the tasks related to designation of Macedonia to become a full member of the EU, because the protection of competition and the implementation of that branch of law is one of the primary objectives for Macedonia as well.

\section{References}

1. Bishop S, Walker M (2002) The Economics of EC Competition Law: Concept, Application and Measurement. Sweet\&Maxwell, London.

2. Boodman M (1993) "The Myth of Harmonization of Laws", International Congress of Comparative Law Montreal 126-130, H.P Glenn., Harmonization of law, foreign and private international law, 1(1993), ERPL, 47-57.

3. Cerovac M (2005) Horizontal concentration of undertakings, Zagreb.

4. Goldstajn A (1974) Commercial Contract Law, Zagreb.

5. Gorenc V (2006) Basics of the Contractual and Status Comemercial Law, Prishtinë.
6. Hetemi M (2005) Some current topics of market economy, Prishtina.

7. Jashari A, Nora Z (2012) Important aspects of concentrations in Republic of Macedonia, International journal of Business Social research, 2: 2.

8. Jashari A, Nora Z (2012) Compatetition law in Macedonia, an important factor for economic development, International journal of Business, Humanities and Tecnology 2: 3.

9. Jones A, Sufrin B (2004) EC Competion Law, Second Edition, Oxford University Press.

10. Karova R, Botta M (2010) "Five Years Enforcement of the Competition Law in the Republic of Macedonia, Time for an Assessment" 2, Mediterranean Competition bulletin 2: 56-72.

11. Mallor A, Barnes J (1998) Business Law and Regulatory Environment, Concepts and Cases.

12. Stoefel E (1998) EU Competion Law, Fribourg.

13. Prajm T (2015) European Intellectual Property Law, Skopje.

14. Van B (2005) Competition law of European Community, Kluwer Law International.

15. Whish R, Bailey D (2012) Competition Law,Sventh edition, Oxford University Press.

16. Law for Protection of Competition. Official Gazette of RM, No. 136/11.

17. Law on General Administrative Procedure. Official Gazette of RM. 38/05, $110 / 08$ and $51 / 1$.

18. The yearly report from the work of the Commission for protection on competition during 2014, March 2015.

19. Law on State aid, Official Gazette of RM, 24/03. 